\title{
Some Suitable Strategies of Economic Development for Developing Countries like Pakistan
}

\author{
Tariq Mahmood ${ }^{1}$ \\ Dr.Abdul Quddus Suhaib \\ ${ }^{1} \mathrm{PhD}$ Scholar, Department of Islamic Studies, B.Z.U. Multan, Pakistan \\ ${ }^{2}$ Professor, Department of Islamic Studies, B.Z.U. Multan, Pakistan
}

\begin{abstract}
In the present world the bitter fact is that mostly people are living in poverty especially in the developing countries. This paper presents some effective policies and strategies for the rehabilitation of poor inhabitants of developing world. The development and prosperity of developing countries depends on the economic condition of their inhabitants. In developing countries, mostly people are engaged with agricultural sector or with labor sector. Due to their low incomes, per capita of developing countries remain low. But by following some strategies and policies this condition may be changed. Furthermore, export of costly products is also hindrances in the way of achieving progress for developing countries. By solving brain drain, lessening their industrial imports and increasing their exports of industrial goods and increasing literacy rate are some suitable strategies discussed. But despite of all policies and strategies, the infrastructure and increasing literacy among the inhabitants of developing countries and the under developed world are also crucial for improving their per capita income and the standard of living. Without improving the standard of living of the under developed world, crimes, diseases and other wrong deeds cannot be decreased until the problem of hunger and ignorance is not solved.
\end{abstract}

Key words: Strategies, Policy, rehabilitation, prosperity, per capita income.

\section{Introduction}

It is historical fact that rich and the poor countries have different strategies and preferences for the development of their countries because all this is done due to availability of resources and the wealth of the country.

For any economy, there are four keys issues the first core issue is that which is referred to as "Determination of Priorities". Man has countless needs and desires but not as many means and resources to fulfill the same. So now one has to decide which desire should get priority and which not. The second core issue is that which no referred to as 'allocation of resources' namely which resources should be allocated for which purpose and in which quantity. The third issue is that which is referred to as "Distribution of income", this means once distribute the income in the society. The fourth issue is referred to as" development in technology of economics," it is basically the question how our economic activities can be developed further so that the production quantity as well as quality of production increased. That new products come into existence and that new economic Venus open up for the people. (1)

With the rise of capitalism, industry and the financial institutions are encouraged which boost up manufacturing industry due to different types of innovations and the encouragement by the capitalistic governments of different countries. 
The rise of manufacturing is usually associated with domestic as well as international tensions. Domestically, new industry is perceived to upset the established rural-urban order, as the political balance shifts from the feudalists to the emerging class of industrialists. Internationally, existing producers react to the competition from new, emerging industrial centers with apprehension as specialization and trading patterns undergo profound changes. The emergence of new sources of manufactures is often taken as an outcome of unfair, even illegitimate, government practices involving commercial policy and currency manipulation. (2) For the development of economy the development of different sectors are important for developing countries especially. Some are as under:

\section{Industry Service}

Industry is also one sector of service in every religion. With this sector, people get their necessities of life while labors and unemployment person get job. If industrialist prepare goods with durable material and with his true intention and he gets prescribed right price of goods from customers. And he pays true wages timely to his workers and to the other staff then this act is reward able. But if he prepare defective or low quality material for profiteering and gaining money illegally or sells his goods more than its prescribed prices then his act is punishable. Then there will be worry able this life and humiliation in the world hereafter. (3)

Industrial sector is encouraged by the different investors and the technicians also as compared to the agricultural sector which has low income and the low chances of improving the standard of living. This is why industrial countries have high per capita income as compared to the agricultural countries.

In Pakistan, the economic base for a larger middle class does not yet exist, the economy and society remain very pyramidal and socio-economic mobility is obstructed by a culture of feudalism, above all, hopes for a new and rising middle class must be tempered by economic facts of life: rampant inflation in Pakistan over the last few years threatens a large number of citizens, making their economically insurance just as the physical dangers increase because of rising terror attacks and for many, the floods of 2010.(4)

According to U.N.O. report which informs about the hurdles of developing countries, this is as under:

"Private businesses face high transaction costs and the security of property is inadequate. Globally those characteristics have been associated with slow economic growth and declining shares of world exports. Moreover, the LDCs (Less Developed Countries) face external hurdles in the form of protected and subsidized markets in developed countries and the formidable competition of china, India and other established Asian exporters". (5)

As concerned the exports of the developing countries, firstly developing countries cannot export furnished and industrial goods, secondly if some have ability to export goods then they have to face problems by the exporters of developed countries. The reasons behind the differences of goods of developing countries and the goods of developed countries are different according to their infrastructures. Some are as under:

1- The resources curse is daunting problem but some countries have successfully deployed resources rent for development and poverty reduction.

2- Traditional products can be source of dynamic, gain through technological upgrading.

3- Relative to the US price Index for manufactured goods, primary product prices are highly volatile but do not show a clear downward trend. This is obviously the case for oil, but it is also true for number of other commodities other minerals. (6)

The framework within which adjustments should be undertaken, have built in trade, industrial and agricultural development policies. These policies should be developed with full recognition given to some of the important changes taking place in the structure of the global economy. (7)

As concerned to the developing countries like Pakistan, they have to face different types of warming conditions. Some signs are as under:

1- Reluctance to deal with economic issues.

2- Inability to rebuild state institution/unwillingness.

3- Absence of governance at the top.

4- Break the begging bowl.

5- Fresh crises with India. (8) 
The most shameful thing is that still in the provinces of Pakistan, consumers are not protected by consumer protection Acts and consumer protection authorities at govt. level due to which mostly consumers are unaware about their rights.

Govt. of Khaber Pakhtun Khaw ( KPK) and Baluchistan has passed the consumers protection Act in $1977 \& 2003$, respectively but fail to establish mechanism for consumer protection. It is further added that in 2004, Governor of Sindh promulgated the Sindh Consumer Protection Ordinance. The same lapsed due to the lack of interest shown by the then Government and the situation is still same.

The Government of the Punjab has enacted the Punjab Consumer Protection has enacted the Punjab Consumer Protection Act (PCPA) 2005, and also implemented the same in its true letter and spirit. This goal is being achieved by establishing District Consumer Courts and District Consumer Protection Councils under the administration of Directorate of Provincial Consumer Protection Council Punjab across the Punjab.( 9).

In Punjab province consumer protection authority became active in the year 2017 after the twelve years later of Punjab Consumer Protection Act. From this the effectiveness of govt. Acts may be visualized.

In order to avoid the mistakes, it may well be recommended that immediate concrete steps be taken:

1- For the whole hearted implementation of existing laws and

2- For the removal of weaknesses and lacunas for efficient consumer redress mechanism.

It is further recommended that quality of human resources available be enhanced by training and education for better implementation of available laws through the provision of efficient grievances redress mechanism and participation of citizens and consumer protection associations be increased by making consumer protection councils functional. (10)

Anyhow, the economy of Pakistan will improve with the existence and inauguration of Gawader port. But some rival countries did not want that Gawadar port could be started in this area.

A real opportunity exists for Pakistan to integrate its economy with the world markets through Gawadar Port. In this regard, the priority given by Pakistan to develop the Gawadar Port is very opportune. Gawadar Port has the potential to complete with regional as well as domestic ports and act as a regional hub. (11)

The Gawadar Port will bring an industrial revolution in the area and generates thousands of jobs. A large support and services set up will also evolve along the entire path of trade flow, generating income opportunities for a large population. In countries like Pakistan single job is the means of living of entire families of average 4-5 family members which would translate into income for millions of Pakistanis. Another facet of this development is the demographic change that would occur at Gawadar and its surrounding areas, relieving population loads at major cities like Karachi. (12)

It is fact that Pak China relations remain in every age of history. So Gawader port will be benefited for the people of Pakistan. But some domestic issues are against the promotion of this port.

Pak- China relations epitomize peaceful co-existence, non-interference and mutual co-operation despite different belief systems and cultures. Both countries supported each other in regional \& global policies.(13)

In the history of Pakistan, from the existence of Pakistan, Pak - China relations remain good and ideal for all the remaining world countries because still there is no example for long term relations for the others. 


\section{Monetary Authority \& Growth}

Anyhow besides the relations of external world, for the domestic countries monetary and fiscal policies are also important. Monetary resources are linked with monetary authorities who fix these resources for different projects.

By setting itself a steady course and keeping to it, the monetary authority could make a major contribution to promoting economic stability. By making that course one of steady but moderate growth in the quantity of money, it would make a major contribution to avoidance of either inflation or deflation of prices. Other forces would still affect the economy, require change and adjustment and disturb the even tenor of our ways. But steady monetary growth would provide a monetary climate favorable to the effective operation of those basic forces of enterprise ingenuity, invention, hard work and thrift that are the true springs of economic growth. (14)

\section{Pakistan's Growth}

As concerned the growth of Pakistan's economy, it remained different in every age of different rulers and even in different dictatorships also. It is because of different policies of different governments regarding their different preferences.

Pakistan's growth record since 1970s underscores that high and persistent inflation is harmful to growth. Periods of high growth episodes tend to be associated with a low inflation environment. Between 1978 and 1971, inflation was 8 percent on average and real per capita growth averaged 3 percent, while real per capita growth fell substantially and averaged only 1 percent. Nonetheless, in light of Pakistan's growth performance and the empirical thresholds beyond which inflation harms growth and financial development, an appropriate inflation target for Pakistan is 5 percent. The SBP's inflation target of 5 percent is, therefore appropriate. (15)

The inflation rate projected by government does not mean that actual in the society this is being applied. Sometimes, in real situation, interest rate is being charged double than the estimated by state bank of Pakistan. But such type of situations occurred in the developing countries mostly and rarely in developed countries.

For the fulfillment of expenditures and different projects, every govt. tries to collect revenues by different sources. The main source is tax collection.

\section{Tax structure Suitability}

It is suitable to collect taxes from the rich class rather than the poor. But unfortunately the rich class of the society in the developing countries like Pakistan's gets concessions and different rebates from the ruling authorities due to different linkages.

The biggest burden of taxes levied on the poorest people... The rent and the malia tax which is received from the poor farmers more than the rich. So, the poor people pay more tax than the rich. And this is very shameful for Pakistanis that we improve taxes on the income of poor man for our Army. (16)

As concerned the purpose of taxes, they may be different by different countries. But generally from these some areas under:

The purposes of tax systems may be as under:

1-To supply adequate revenue;

2-To achieve a practical and workable tax system;

3-To establish horizontal and vertical equity;

4-To achieve economic stability;

5-To reduce economic inequality;

6-To avoid impairment of the market-oriented economy and; 
But unfortunately sometimes objectives are practically different than theoretically. Therefore, rather than diminishing inequalities, inequalities increase from the insatiability of tax system of the society. This thing is anti development policy and enhances the difference of the rich and the poor class.

A good deal of confusion prevails, even among eminent Muslim writers, regarding the concept of taxation in Islam. This confusion has become be wildering and at times misleading in the hands of many western writers who, otherwise, have made outstanding contributions to Islamic studies by providing the historical material, which makes possible comparative approach in Muslim studies which was lacking in many early Muslim writers.(18)

Anyhow, tax collection and tax culture of Muslim states are quite different than the non Muslim states because different kinds of taxes of welfare.

The main taxes that were levied during the earlier Islamic period were as follows:

1- Zakat- poor due;

2- Ushr-tithe;

3- Kharaj-land tax, levied in conquered countries in lieu of tithe usually levied on non- Muslims especially in the earlier centuries of Muslim rule, but in variably so.

4- Jizyah-pool tax or capitation-tax.

5- Taxes in kind taken from the subject population as a partial payment of taxes to supply provisions etc. for military.

6- Tribute- payments of fixed sums of money for towns and lands retained under treaty of capitulation, and similar payments obtained under compulsion from foreign countries.

7- Ghanimah- one-fifth of the booty falling to the state treasury.

8- Tax on commerce, commercial wars, etc. zakat or poor-tax. The Prophet has described zakat as wealth in taken from the rich and returned to the poor. (19)

\section{Sources of Income}

According to Athar Husain, the sources of income areas under:

1. Ushr or tithe;

2. Kharaj or land tax;

3. Jizyah or pool tax;

4. zakat;

5. Sadqat;

6. Fayor booty obtained from enemy without a fight;

7. Khums or booty obtained from enemy without a fight;

8. Zaraib taxes imposed on a temporary basis for public good;

9. Kharaiz or rent of Government lands;

10. Ushoor or duty imported goods;

11. Wakaf;

12. Miscellaneous sources like mines and minerals etc. (20)

\section{Distinctive features of Agricultural taxation}

There are many features, from them some as under:

1-Land is a crucial input so that the problems with taxing rent must play a role.

2-The government is after the main or only supplier of vital inputs such as water and electricity so that its pricing policy must be integrated into the taxation of production.

3-Food, its availability, distribution and price is of such importance to welfare that all governments have to take some responsibility for its price, quality and security. (21) 
Ecology and Technology

Industrial technologies are inherently damaging to environment; outcomes are not foreseeable; there are not solutions to all problems; mistakes are inevitable part of the industrial system.

\section{Computerization and Information Technology}

No doubt, in the age of globalization, information technology is crucial for developing countries but the basic structure of different organizations is still low and the problem of electrical electronics still lies.

Computers and I.T. do not represent a potentially libratory technology. As well as being the product of a vast technological structure, they channel a limited form of information which is amenable to, and representative of capital. (22)

\section{Brain Drain \& Side effects}

1-High skilled emigrants do not pay taxes in their home country once they have left, as education is partly or totally subsidized by the government, emigrants leave before they can repay their debt to society.

2-Another negative effect is inducing shortage of man power in key activates as when engineers or health professionals emigrants in disproportionately large numbers undermining a country's ability to adopt new technologies or deal with health crises.

3-The brain drain increases the technological gap between leading and developing nations because the concentration of human capital in the most advanced economies contribute to their technological progress.(23)

\section{Present Condition of Pakistan regarding Higher Education}

Pakistan has now over 170 universities in Public and private universities more than this figure. Most of all universities from this figure have M Phil and $\mathrm{PhD}$ programs in different disciplines.

Higher Education Commission deserves the main credit for this rapid and ambitions growth of higher education in Pakistan. However, a degree Program at a University can only be as good as the availability of well trained faculty research equipment and funds for supplies, and for the faculty and students to have work visits to institutions with world class expertise in their fields of interest. However, at present, these programs are at too small a level to meet the needs and have a little impact on the improvement of higher education in Pakistan. A high priority status and a major effort from Prime Minister's office are required.(24)

\section{Employment Opportunities}

In Pakistan, it is bitter fact that employment opportunities for the graduates of different institutions are also different. This is against the equity and justice. Especially for the graduates of Urdu medium institutions and for the graduates of madaris, job opportunities are very less. Due to this, unemployed persons of these institutions remain unemployed and have lesser standard of living as compared to other graduates of other institutions.

Students of religious institutions must receive the same facilities as students of worldly education in respect of hostel, scholarship sports and remuneration after employment as teachers of Basic Islam. It logically follows that status of teachers must be raised for successful implementation of the ideology.(25) 


\section{Some Foreign Experts' opinion}

There are five or six necessary things to happen before Pakistan can be safely put in the 'normal' category. These include relations with India, a revived economy, a repaired state, a rebalanced civil-military relationship, a redefined role of the military in the state, fighting domestic insurgencies more effectively, allowing reshaped police force to emerge and finding a new role for Pakistan visa- via its neighbor, notably India. The politicians would have to moderate their disputes concentrating on issues and reform, and not patronage and corruption. However, none of these would seem to be a sufficient factor that trumps all others. (26)

But according to my opinion, relations with India if these would have been changed then the need of tight border security and expenses on security issues will also declined. These declined expenses will be used on improving the infrastructure and the literacy level. In this way, future will be brighter than expected but due to some external powers, Pak-India relation will not become friendly. Contemporary globalization is most commonly associated with the huge burst of trade, telecommunication and rapid movements of people over long distances. Pakistan was among the least prepared states for this most recent surge of globalization. It had seriously underinvested in education at all levels and its economy does not produce many goods or services in high demand.(27)

That Pakistan is a unique country is beyond doubt or debate. Had it not been a truly unique country, or if it had been a slightly less unique than it actually is, it would not have survived the tomfoolery of its leaders and their kith and kin and their dear and near ones. It is actually so unique that it has survived all these years despite such blatant contradictions where leaders talk of the 'primary of knowledge' even when they are directly responsible for disrupting the process of knowledge acquisition. (28)

Physically, Pakistan is unique because it is developing in sense but the style of ruling authorities show that they belong to developed countries because of luxurious spending. In the case of Panama leaks, some ruling authorities of Pakistan became clear and sentenced by Supreme Court of Pakistan on the reference of NAB authorities. While in the developed countries of world, the ruling authorities and their organizations also try to improve the standard of their inhabitants with welfare works and providing different relieves. In a market-Oriented economy like Japan's, government support in the form of subsides to target industries is rarely a vital ingredient in the nation's general economic growth, even though it may be temporarily beneficial to the favored industries. (29)

\section{Conclusions/Findings}

To sum up, Strategic policies should not be denounced outright. Some may benefit not only the home country but also the foreign countries. On the other hand, certain strategic policies benefit the home countries. The difference is that, in the former the policies help to reduce the social production cost (that is, the sum of production costs incurred by private firms and the cost of government support) while, in the later policies help to reduce private cost without charging the social production cost. (30)

As concerned the role of inhabitants in the way to achieve long term goals for the development, is also crucial and have linkage with Govt. organizations and ruling authorities in positive sense.

It is the duty of every Pakistani to have something for the socio-economic development of his homeland. The present attitude of every one trying to benefit without making any effort to add to the GNP and accelerate the rate of growth in basic needs of life, can never attain the goal. If everyone wants to eat fresh fruit but never plants trees, the net result is obvious. If new orchards of development grow in every sector of our life, the dream of a welfare state can become a reality. If the habit of compulsory saving, hard work, greater production and quality improvement become our ideals as well as practice, the picture can change for the better earlier. (31) 
With the mutual co-operation of people of Pakistan with the ruling authorities, by declining their luxurious spending and giving poor dues to the needy and the deprived people, inequality among the different sections of society.

\section{References}

[1] Qasmi Naseem Ahmad, "Economy, the Islamic Approach", Z. Baintner (translator), Karachi: Darul-Ishaaat, 1st edition, 2009, pp-18-19.

[2] Irfan-ul-Haq, "Theory at odds with best practice: the travails of industrial policy", The Lahore Journal of Economics", 20: Se (September 2015), P-88.

[3] Abdul Rehman Khan (compiler), “ Islam ka Musharti Nizaam”, Multan: Aalmi Idara Ishaat Uloome Islamiya, ist edition1983, p-113.

[4] Stephen P. Cohen (compiler), “ The future of Pakistan" (report), the Bookings institution, Washington D.C., January 2011,pp-23-24.

[5] UNCTAD Project, United Nations Conference on trade \& export competitiveness \& development in LDCs: policies, Issues a\& priorities..., Geneva Switzerland:2008,p-1.

[6] Ibid, p-17.

[7] Shahid Javaid Burki, "Industrial policy: Domestic Challenges, global imperatives\& Pakistan choice", The Lahore Journal of Economics Special Edition, Sep.2008, p-26.

[8] Stephen P. Cohen (compiler), "The future of Pakistan" (report), the Bookings institution, Washington D.C., January 2011,pp-56-57.

[9] Saeed akhtar Ansari (director),'International Judicial Conference , held in Supreme court Building Islamabad held on $19^{\text {th }}$ to $21^{\text {st }}$ April 2013,p-2.

[10] Asad Ajmal, "Consumer Protection in Pakistan”, Retrieved from www.supremecourt.gov.pk/ijc/articles/18/3..pdf. retrieved on $4^{\text {th }}$ july 2013 , p-13.

[11] Ammad Hassan," Pakistan's Gawader Port- Prospects of economic revival"(master thesis), U.S.A: Naval post graduate school California, 2005, p-23.

[12] Ibid.p-37.

[13] Umbreen Javaid \&Arifa Jahangir, "Pakistan china strategic relationship glorious journey of 55 years", JRSP,Vol. 52 issue number 1,January-June 2015, p-179.

[14] Milton Friedman, “The role of monetary policy", The American Economic Review, Volume Lviii , issue number 1,March 1968, p-17.

[15] Mohsan S Khan \& Axel Schimmelpennig, "Inflation in Pakistan", The Pakistan Development Review Issue number 45:2, Summer 2006, p-200

[16] Sayyed Muhammad Mian Maulana, “Ulamaey Hind ka Shandar Mazi”, Karachi: Maktaba Rashidiyya,N/M., p-38.

[17] Pramod K. Rai, " The challenges of tax collection in developing economics with special reference to India", (LLM thesis), Athens Georgia: University of Georgia Law, 2004, p-3.

[18] Anwar Iqbal Qureshi, “Fiscal system of Iran”, Lahore: institute of Islamic Culture,ist edition 1978, p-1.

[19] Ibid,p-26.

[20] Athar Husain, "The glorious caliphate”, Lahore: Islamic book Foundation,1400 A.H./ 1980 A.D.p-200.

[21] H.Chenery \& T.N. Srinivas, (editor) “Taxation for developing countries”, U.K: Elesvier Science Publishing, 1989, p1071.

[22] Jonathan Purkis \& James Bowen, “ Changing Anarchism” Manchester \& New York: Manchester university press, $1^{\text {st }}$ edition 2004, p-90.

[23] Frederic Docquier, "Brain Drain of developing countries is a world of labor", evidence based policy making, May 2014,p-5.

[24] Khalid Iqbal Dr., “ We need more doctors in this house”, Lahore/ Karachi: The daily newspaper dawn, dated $3^{\text {rd }}$ November, 2013. P-10.

[25] A.M.Khan Dr., "Implementation of Islamic ideology in third world", Multan: Saqib Art Press, 1400 A. H/ 1980 A.D.p145.

[26] Stephen P. Cohen (compiler), “ The future of Pakistan” (report), p-55.

[27] Ibid. p-46.

[28] Humair Ishtiaq, "Ghost Schools and brain dead leaders”, Lahore/ Karachi: daily dawn newspaper, $3^{\text {rd }}$ November 2013. P-10.

[29] Katsuro Sakoh, “Japanese Economic Success: Industrial policy or free market?”Cato Journal, Vol. 4 Issue number 2, Fall 1984. P-542.

[30] Paul Krugman, “ Trade with Japan: Has the door opened wider?”, U.S.A.: University of Chicago Press, 1991 , p-274.

[31] A.M.Khan Dr., "Implementation of Islamic ideology in third world", Multan: Saqib Art Press, 1400 A. H/ 1980 A.D.p59. 